\title{
Penggunaan LKS Berbasis Learning Cycle-5e Pada Pembelajaran Tata Nama Senyawa Anorganik
}

\author{
Andria Evina ${ }^{1,2}$ \\ ${ }^{1}$ Guru SMAN 1 Kahayan Tengah, Kalimantan Tengah, Indonesia \\ ${ }^{2}$ Mahasiswa Program Studi Pendidikan Kimia, PPS Universitas Palangka Raya, \\ Indonesia \\ email: andria_chemistry@yahoo.com
}

\begin{abstract}
Abstrak. Penulisan kajian ini bertujuan mengkaji penggunaan LKS berbasis Learning Cycle-5E pada pembelajaran tata nama senyawa anorganik. Untuk mempelajari tata nama senyawa anorganik diperlukan pengetahuan tentang konsep Redoks terutama bilangan oksidasi. Adanya kesulitan dalam memahami suatu konsep maka akan berakibat terjadinya kesulitan pula dalam memahami konsep berikutnya. Oleh karena itu, siswa dituntut untuk berperan aktif dan bertanggung jawab terhadap proses dan hasil belajar, pembelajaran seperti ini disebut pembelajaran yang berpusat pada siswa atau Student Centered. Siswa diharapkan mampu mengkonstruksi sendiri pengetahuan-pengetahuan yang harus dimiliki berdasarkan pengetahuan yang sudah dimiliki sebelumnya. Penggunaan LKS berbasis Learning Cycle-5E pada pembelajaran tata nama senyawa anorganik diharapkan dapat menghasilkan pembelajaran yang bermakna, sehingga hasil belajar dan kemampuan berpikir siswa meningkat. Pembelajaran kimia yang bermakna terwujud karena implementasi Learning Cycle-5E sesuai dengan prinsip pembelajaran konstruktivisme yang dilakukan melalui kegiatan Engagement, Eksplorasi, Eksplanasi, Elaborasi, dan Evaluasi.
\end{abstract}

Kata kunci: LKS, Learning Cycle-5E, tatanama senyawa anorganik

\section{PENDAHULUAN}

Pemberlakuan kurikulum 2013 menekankan peranan siswa lebih aktif dalam pembelajaran melalui berbagai model pembelajaran konstruktivisme. Kurikulum 2013 juga diharapkan dapat membantu siswa untuk meningkatkan keterampilan berpikir tingkat tinggi (HOTS), karena berpikir tingkat tinggi dapat mendorong siswa untuk berpikir secara luas dan mendalam tentang materi pelajaran.

Standar Proses dikembangkan mengacu pada Standar Kompetensi Lulusan dan Standar Isi yang telah ditetapkan sesuai dengan ketentuan dalam Peraturan Pemerintah Nomor 19 Tahun 2005 tentang Standar Nasional Pendidikan sebagaimana telah diubah dengan Peraturan Pemerintah Nomor 32 Tahun 2013 tentang Perubahan atas Peraturan Pemerintah Nomor 19 Tahun 2005 tentang Standar Nasional Pendidikan. Proses Pembelajaran pada satuan pendidikan diselenggarakan secara interaktif, inspiratif, menyenangkan, menantang, memotivasi peserta didik untuk berpartisipasi aktif, serta memberikan ruang yang cukup bagi prakarsa, kreativitas, dan kemandirian sesuai dengan bakat, minat, dan perkembangan fisik serta psikologis peserta didik.

Kurangnya pengembangan keterampilan berpikir tingkat tinggi dalam proses pembelajaran, mengakibatkan pemahaman siswa terhadap konsep-konsep yang dipelajari masih relatif rendah. Dalam asesmen global yang dilakukan oleh Programme for International Student Assessment (PISA) sejak tahun 2000 hingga 
2012 dalam kurun waktu tiga tahun, Indonesia dalam hal literasi sains selalu memperoleh skor jauh di bawah nilai rata-rata.

Tabel 1.1 Posisi Indonesia dibandingkan Negara Lain Berdasarkan Studi PISA

\begin{tabular}{|c|c|c|c|c|c|}
\hline $\begin{array}{l}\text { Tahun } \\
\text { Studi }\end{array}$ & $\begin{array}{c}\text { Mata } \\
\text { Pelajaran }\end{array}$ & $\begin{array}{l}\text { Skor Rata- } \\
\text { rata } \\
\text { Indonesia }\end{array}$ & $\begin{array}{c}\text { Skor Rata-rata } \\
\text { Internasional }\end{array}$ & $\begin{array}{l}\text { Peringkat } \\
\text { Indonesia }\end{array}$ & $\begin{array}{c}\text { Jumlah } \\
\text { Negara } \\
\text { Peserta Studi }\end{array}$ \\
\hline \multirow{3}{*}{2000} & Membaca & 371 & 500 & 39 & \multirow{3}{*}{41} \\
\hline & Matematika & 367 & 500 & 39 & \\
\hline & Sains & 393 & 500 & 38 & \\
\hline \multirow{3}{*}{2003} & Membaca & 382 & 500 & 39 & \multirow{3}{*}{40} \\
\hline & Matematika & 360 & 500 & 38 & \\
\hline & Sains & 395 & 500 & 38 & \\
\hline \multirow{3}{*}{2006} & Membaca & 393 & 500 & 48 & \multirow{3}{*}{57} \\
\hline & Matematika & 391 & 500 & 50 & \\
\hline & Sains & 393 & 500 & 50 & \\
\hline \multirow{3}{*}{2009} & Membaca & 402 & 500 & 57 & \multirow{3}{*}{65} \\
\hline & Matematika & 371 & 500 & 61 & \\
\hline & Sains & 383 & 500 & 60 & \\
\hline \multirow{3}{*}{2012} & Membaca & 375 & 494 & 64 & \multirow{3}{*}{65} \\
\hline & Matematika & 396 & 496 & 64 & \\
\hline & Sains & 382 & 501 & 64 & \\
\hline
\end{tabular}

Soal-soal literasi sains dalam PISA merupakan soal-soal yang menuntut siswa agar mampu menggunakan kemampuan berpikir tingkat tinggi (high order thinking skill) (Mariya, 2016)

Hal ini terjadi karena, pada proses pembelajaran siswa kurang kreatif sebab banyak berpusat pada guru (teacher centered) sehingga pembelajaran bersifat monoton. Soal-soal yang disajikan guru lebih banyak masih bersifat LOTS (Low Order Thinking Skill) yaitu kemampuan mengingat kembali informasi (recall) sehingga siswa belum mampu mengkonstruksi pengetahuannya sendiri dan proses pembelajaran tidak efektif dan efisien. Belum tersedia sumber belajar yang dapat membantu siswa untuk mengeksplorasi ide-ide mereka hingga memperoleh pengetahuan baru dengan sendirinya serta membiasakan siswa untuk berpikir secara mandiri dan kritis.

Agar bermakna, belajar tidak cukup dengan hanya mendengar dan melihat tetapi harus dengan melakukan aktivitas (membaca, bertanya, menjawab, berkomentar, mengerjakan, mengkomunikasikan, presentasi, diskusi). Salah satu model pembelajaran yang berorientasi pada pengembangan keterampilan berpikir tingkat tinggi adalah model Learning Cycle-5E. Agar pembelajaran dengan model Learning Cycle-5E berlangsung dengan efektif dan efisien diperlukan sumber belajar yang memadai, misalnya dalam bentuk LKS.

Pada LKS berbasis Learning Cycle-5E, siswa dapat menemukan arahan yang terstruktur untuk memahami materi yang diberikan. Sehingga proses pembelajaran bersifat student centered. Dalam proses pembelajaran terjadi penerimaan informasi dan kemudian diolah sehingga menghasilkan produk dalam bentuk hasil belajar dan diharapkan dapat mengembangkan kemampuan berpikir tingkat tinggi.

Kajian ilmu kimia sebagian besar bersifat abstrak (seperti ion, molekul, senyawa, entalpi), karakteristik kimia yang demikian itu, membuat mata pelajaran kimia menjadi salah satu pelajaran yang dianggap sulit oleh siswa. Kurangnya pemahaman mengenai konsep-konsep abstrak ini, dapat dicegah sama sekali bila proses pembelajaran dalam kelas menggunakan metoda atau pendekatan pembelajaran yang sesuai dengan potensi dan kondisi siswanya. Salah satu model 
pembelajaran yang dapat digunakan dalam pembelajaran kimia adalah pembelajaran Learning Cycle. Pembelajaran Learning Cycle sangat cocok digunakan untuk mengajarkan materi yang banyak melibatkan konsep, prinsip, aturan serta perhitungan secara matematis. Sehingga sesuai jika diterapkan pada pokok bahasan tata nama senyawa anorganik yang memerlukan suatu pemahaman konsep.

Berdasarkan hasil beberapa penelitian ditemukan masih banyak siswa SMA kelas $\mathrm{X}$ yang pemahamannya tentang konsep tata nama senyawa kimia tergolong rendah. Masih banyak siswa yang belum hafal dengan nama maupun lambang unsur yang sering disebutkan dalam pembelajaran kimia. Hal ini menyebabkan siswa seringkali melakukan kesalahan dalam menyebutkan nama suatu senyawa dari rumus kimia yang diberikan dan berpengaruh pada prestasi belajar siswa. Hal ini menunjukkan siswa kesulitan memahami materi tata nama senyawa anorganik.

Hasil penelitian Fransiska Pipil (2012) menunjukkan bahwa salah satu penyebab pembelajaran kimia tidak menarik minat siswa karena penggunaan metode ceramah yang sering diterapkan oleh guru sehingga siswa cenderung sulit memahami materi. Hal ini yang menyebabkan rendahnya hasil belajar kimia siswa pada materi tata nama senyawa kimia. Hasil penelitian Nikmatur Rohmah (2011) menunjukkan bahwa hasil belajar siswa yang pembelajarannya menggunakan model pembelajaran Learning Cycle-5E lebih tinggi daripada siswa yang pembelajarannya menggunakan metode konvensional.

Oleh karena itu, guru dapat mengembangkan proses pembelajaran terutama sumber belajar yang mampu mengekspos ide-ide siswa menjadi sesuatu yang berharga dan bermanfaat bagi dirinya. Makalah ini membahas tentang bagaimana penggunaan LKS berbasis Learning Cycle-5E pada pembelajaran tata nama senyawa anorganik.

\section{PEMBAHASAN}

\section{Teori Belajar Konstruktivisme}

Konstruktivisme adalah sebuah filosofi pembelajaran yang dilandasi premis bahwa dengan merefleksikan pengalaman, kita membangun, mengkonstruksi pengetahuan pemahaman kita tentang dunia tempat kita hidup. Belajar, dengan demikian, semata-mata sebagai suatu proses pengaturan model mental seseorang untuk mengakomodasi pengalaman-pengalaman baru. Asumsiasumsi dasar dari konstruktivisme seperti yang diungkapkan oleh Merril (1991) dalam Suyono (2011:106) adalah sebagai berikut:

(1) Pengetahuan dikonstruksikan melalui pengalaman.

(2) Belajar adalah penafsiran personal tentang dunia nyata.

(3) Belajar adalah sebuah proses aktif dimana makna dikembangkan berdasarkan pengalaman.

Berikut teori konstruktivisme menurut beberapa ahli:

\section{a. Teori Konstruktivisme Piaget}

Teori Piaget berlandaskan gagasan bahwa perkembangan anak bermakna membangun struktur kognitifnya atau peta mentalnya yang diistilahkan "schema/skema (jamak = schemata/skemata)", atau konsep jejaring untuk memahami dan menanggapi pengalaman fisik dalam lingkungan sekelilingnya. Menurut teori konstruktivisme pengetahuan tidak dapat ditransfer begitu saja dari pikiran guru kepada pikiran siswa. Artinya, siswa harus aktif secara mental 
membangun struktur pengetahuannya berdasarkan kematangan kognitif yang dimilikinya.

Karplus dan Their (dalam Renner et al, 1988) mengembangkan strategi pembelajaran yang sesuai dengan ide Piaget. Dalam hal ini pembelajar diberi kesempatan untuk mengasimilasi informasi dengan cara mengeksplorasi lingkungan, mengakomodasi informasi dengan cara mengembangkan konsep, mengorganisasikan informasi dan menghubungkan konsep-konsep baru dengan menggunakan atau memperluas konsep yang dimiliki untuk menjelaskan suatu fenomena yang berbeda. Implementasi teori Piaget oleh Karplus dikembangkan menjadi fase eksplorasi, pengenalan konsep, dan aplikasi konsep. Unsur-unsur teori belajar Piaget (asimilasi, akomodasi, dan organisasi) mempunyai korespondensi dengan fase-fase dalam Siklus Belajar (Learning Cycle).

\section{b. Teori Konstruktivisme Sosial Vygotsky}

Vygotsky mengungkapkan pentingnya faktor-faktor sosial dalam belajar. Selama belajar, terdapat saling pengaruh antara bahasa dan tindakan dalam kondisi sosial. Vygotsky mengemukakan bahwa belajar itu harus berlangsung dalam kondisi sosial, terlihat betul peranan bahasa dalam belajar konstruktif. Mengenai belajar sains, Vygotsky menyarankan bahwa interaksi sosial itu penting saat siswa menginternalisasi pemahaman-pemahaman yang sulit, masalahmasalah dan proses. Selanjutnya, proses internalisasi melibatkan rekonstruksi aktivitas psikologis dengan dasar penggunaan bahasa. Jelas tampak bahwa penggunaan bahasa secara aktif yang didasarkan pemikiran merupakan sarana bagi para siswa untuk menegosiasi kebermaknaan pengalaman-pengalaman mereka.

Secara garis besar, prinsip-prinsip Konstruktivisme yang diterapkan dalam belajar mengajar adalah:

1. Pengetahuan dibangun oleh siswa sendiri.

2. Pengetahuan tidak dapat dipindahkan dari guru ke murid, kecuali hanya dengan keaktifan murid sendiri untuk menalar.

3. Murid aktif megkontruksi secara terus menerus, sehingga selalu terjadi perubahan konsep ilmiah.

4. Guru sekedar membantu menyediakan sarana dan situasi agar proses kontruksi berjalan lancar.

5. Menghadapi masalah yang relevan dengan siswa.

6. Struktur pembalajaran seputar konsep utama pentingnya sebuah pertanyaan.

7. Mencari dan menilai pendapat siswa.

8. Menyesuaikan kurikulum untuk menanggapi anggapan siswa.

\section{Pembelajaran Bermakna}

Istilah "pembelajaran bermakna" dalam kajian ini diadopsi dari istilah "meaningfull learning" atau belajar bermakna yang digunakan oleh Ausabel pada tahun 1969. Ausubel (Dahar, 1996) menyatakan bahwa belajar dapat diklasifikasikan kedalam dua dimensi. Dimensi pertama berkaitan dengan bagaimana cara informasi atau materi ajar tersebut disajikan pada peserta belajar, apakah melalui penerimaan atau penemuan. Pada dimensi pertama ini, informasi materi ajar dapat dikomunikasikan pada peserta belajar baik dalam bentuk belajar penerimaan yang menyajikan informasi itu dalam bentuk final, maupun dalam bentuk belajar penemuan yang mengharuskan peserta belajar menemukan sendiri 
sebagian atau seluruh materi yang diajarkan. Dimensi kedua menyangkut cara bagaimana peserta belajar dapat menghubungkan informasi itu pada struktur kognitif yang telah ada. Struktur kognitif oleh Ausubel dimaknai sebagai faktafakta, konsep-konsep dan generalisasi-generalisasi yang telah dipelajari dan diingat oleh peserta belajar. Pada dimensi kedua ini, "belajar bermakna" terjadi jika peserta belajar dapat menghubungkan atau mengaitkan informasi itu pada pengetahuan (berupa konsep-konsep dan lain-lain) yang telah dimilikinya. Akan tetapi, jika peserta belajar hanya mencoba-coba menghapalkan informasi baru itu tanpa mengkaitkannya dengan konsep-konsep yang telah ada dalam struktur kognitifnya, maka dalam hal ini hanya terjadi "belajar hapalan".

Dapat disimpulkan bahwa belajar bermakna pada dasarnya merupakan suatu proses mengaitkan informasi barupada konsep-konsep relevan yang terdapat dalam struktur kognitif seseorang. Dengan demikian pembelajaran bermakna dapat dimaknai sebagai suatu upaya yang dilakukan oleh guru untuk mengelola informasi belajar (berupa konsep dan lain-lain) dalam kegiatan pembelajaran agar peserta belajar mampu mengkaitkan informasi belajar tersebut dengan informasi belajar yang telah ada dalam struktur kognitifnya atau yang telah dimilikinya (Widhy, 2012).

\section{Learning Cycle-5E}

Model pembelajaran ini dikembangkan dari teori perkembangan kognitif Piaget. Teori belajar Piaget memiliki konsep yaitu pengetahuan awal yang dimiliki oleh siswa dikaitkan dengan pengetahuan baru yang diperoleh oleh siswa. Unsur-unsur teori belajar Piaget yang meliputi fase asimilase, akomodasi dan organisasi mempunyai korespondensi dengan fase-fase dalam learning cycle 5E (Dasna dalam Diana Deri, 2015:7).

Menurut Ergin (2012) dalam Diana Deri (2015:7), model learning cycle 5E mempunyai salah satu tujuan yang memberikan kesempatan kepada siswa untuk mengkonstruksi pengetahuan dan pengalaman siswa dengan terlibat secara aktif mempelajari materi secara bermakna dengan bekerja dan berpikir baik secara individu maupun kelompok, sehingga siswa dapat menguasai kompetensikompetensi yang harus dicapai dalam pembelajaran.

Learning cycle merupakan salah satu model pembelajaran dengan pendekatan konstruktivis yang pada mulanya terdiri atas tiga tahap, yaitu: eksplorasi (exploration), menjelaskan (explanation), dan memperluas (elaboration/extention), yang dikenal dengan learning cycle 3E. Pada proses selanjutnya, tiga tahap siklus tersebut mengalami perkembangan menjadi lima tahap, yaitu: pembangkitan minat/mengajak (engagement), eksplorasi/menyelidiki (exploration), menjelaskan (explanation), memperluas (elaboration/extention), dan evaluasi (evaluation), sehingga dikenal dengan learning cycle $5 E$.

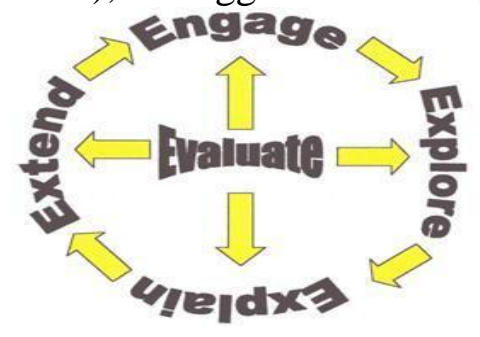


Fajaroh (2008) dalam Sumarna (2014) menyatakan bahwa kelima tahap learning cycle $5 E$ tersebut dijelaskan sebagai berikut:

1) Engagement (mengajak), yaitu fase yang bertujuan mempersiapkan diri siswa agar terkondisi dalam menempuh fase berikutnya dengan jalan mengeksplorasi pengetahuan awal dan ide-ide mereka, serta untuk mengetahui kemungkinan terjadinya miskonsepsi pada pembelajaran sebelumnya. Dalam fase engagement ini minat dan keingintahuan siswa tentang topik yang akan dipelajari berusaha dibangkitkan. Siswa juga diajak membuat prediksi-prediksi tentang fenomena yang akan dipelajari dan dibuktikan dalam tahap eksplorasi.

2) Exploration (menyelidiki), pada fase ini siswa diberi kesempatan untuk bekerjasama dalam kelompok-kelompok kecil tanpa pengajaran langsung dari guru untuk menguji prediksi, melakukan dan mencatat pengamatan serta ideide melalui kegiatan-kegiatan seperti praktikum dan telaah literatur.

3) Explanation (menjelaskan), dalam fase ini guru mendorong siswa untuk menjelaskan konsep dengan kalimat mereka sendiri, meminta bukti dan klarifikasi dari penjelasan mereka, dan mengarahkan kegiatan diskusi. Pada tahap ini siswa menemukan istilah-istilah dari konsep yang dipelajari.

4) Elaboration/Extention (memperluas), yaitu siswa menerapkan konsep dan keterampilan dalam situasi baru melalui kegiatan-kegiatan seperti praktikum lanjutan dan problem solving.

5) Evaluation (evaluasi), dilakukan evaluasi terhadap efektifitas fase-fase sebelumnya dan juga evaluasi terhadap pengetahuan, pemahaman konsep atau kompetensi siswa melalui problem solving dalam konteks baru yang kadangkadang mendorong siswa melakukan investigasi lebih lanjut.

Menurut Fajaroh (2008) seperti dikutip oleh Sumarna (2014), model pembelajaran learning cycle $5 E$ memiliki beberapa kelebihan, diantaranya:

1. Merangsang siswa untuk mengingat kembali materi pelajaran yang telah mereka dapatkan sebelumnya.

2. Memberikan motivasi kepada siswa untuk lebih aktif dalam pembelajaran dan menambah rasa keingintahuan.

3. Melatih siswa belajar menemukan konsep.

4. Melatih siswa untuk menyampaikan secara lisan konsep yang telah mereka pelajari.

5. Memberi kesempatan kepada siswa untuk berpikir, mencari, menemukan dan menjelaskan contoh penerapan konsep yang telah dipelajari.

Berikut akan disajikan beberapa dari hasil penelitian mengenai penerapan Learning Cycle-5E pada pembelajaran kimia, yaitu:

1. Febriana Adam, Endang Budiasih, Dedek Sukarianingsih tahun 2013. Universitas Negeri Malang. Perbedaan Hasil Belajar Materi Hidrokarbon Pada Penerapan Model Pembelajaran Learning Cycle 5 Fase dan Learning Cycle 5 Fase-Reciprocal Teaching Bagi Siswa Kelas X MAN Malang 1. Hasil penelitian menunjukkan ada perbedaan hasil belajar siswa yang diajar dengan model pembelajaran Reciprocal Teaching dalam Learning Cycle 5 fase dengan siswa yang diajar dengan model pembelajaran Learning Cycle 5 fase. Hasil keterlaksanaan pembelajaran kedua kelas berjalan dengan baik dengan persentase skor penilaian $84,38 \%$ untuk kelas kontrol, dan $87,05 \%$ untuk 
kelas eksperimen. Hasil belajar afektif siswa menunjukkan nilai rata-rata 76 untuk kelas eksperimen dan 73 untuk kelas kontrol.

2. Ninis Sulistyowati, Suyatno, dan Sri Poedjiastoeti, tahun 2014 Universitas Negeri Surabaya. Pembelajaran Kimia dengan Model Learning Cycle 5E untuk Meningkatkan Penguasaan Konsep dan Keterampilan Berpikir Kritis Siswa SMK Pada Pokok bahasan Termokimia. Hasil penelitian menunjukkan bahwa perangkat pembelajaran yang dikembangkan dinyatakan valid dan dapat digunakan dalam pembelajaran. Sebanyak 8 siswa $(80 \%)$ dinyatakan tuntas belajar dengan skor rata-rata penguasaan konsep sebesar 82,32 dan rata-rata gain score 0,73 . Dengan demikian peningkatan penguasaan konsep dan keterampilan berpikir kritis siswa berada pada kategori tinggi. Berdasarkan hasil analisis korelasi Pearson Product Moment antara penguasaan konsep siswa dengan keterampilan berpikir kritis siswa, diperoleh korelasi sebesar 0,754. Koefisien korelasi tersebut terbukti signifikan pada uji signifikansi koefisien korelasi. Hal tersebut menunjukkan adanya korelasi positif yang signifikan antara penguasaan konsep siswa dengan keterampilan berpikir kritis siswa.

3. Fajar Nugroho, I Wayan Dasna, dan Sri Rahayu tahun 2016 Universitas Negeri Malang, Pengaruh Learning Cycle 5E-Problem Posing terhadap Hasil Belajar dan Kemampuan Berfikir Tingkat Tinggi Siswa dengan Kemampuan Awal Berbeda pada Materi Kelarutan dan Hasil Kali Kelarutan. Hasil penelitian: (1) Terdapat perbedaan hasil belajar, (2) Terdapat perbedaan kemampuan berfikir tingkat tinggi. Learning cycle 5E-problem posing dapat meningkatkan hasil belajar dan kemampuan berfikir tingkat tinggi, (3) Terdapat pengaruh kemampuan awal terhadap hasil belajar, (4) Tidak ada pengaruh kemampuan awal terhadap kemampuan berfikir tingkat tinggi, (5) Tidak ada interaksi antara kemampuan awal dan model pembelajaran terhadap hasil belajar dan kemampuan berfikir tingkat tinggi.

4. Natalia Dyah Hapsari, Mohammad Maskury dan Sri Yamtinah, tahun 2015 Universitas Sebelas Maret Surakarta, Pengembangan Lembar Kegiatan Siswa (LKS) Kimia SMA/MA Berbasis Learning Cycle 5E pada Materi Laju Reaksi. Hasil penelitian menunjukkan: (1) Telah berhasil dikembangkan Lembar Kegiatan Siswa (LKS) berbasis Learning Cycle-5E pada materi Laju Reaksi yang dilakukan berdasarkan tahapan penelitian dan pengembangan R\&D yang terdiri dari 9 tahapan, (2) Kualitas Lembar Kegiatan Siswa (LKS) berbasis Learning Cycle-5E pada materi laju Reaksi memiliki kualitas sangat baik pada aspek komponen kelayakan isi, bahasa, penyajian dan kegrafisan dengan persentase sebesar $84,06 \%$ berdasarkan penilaian siswa dan 90,88\% berdasarkan penilaian guru, (hasil uji efektivitas pada aspek pengetahuan terdapat perbedaan antara kelas eksperimen (pembelajaran dengan model Learning Cycle-5E disertai Lembar Kegiatan Siswa (LKS) berbasis Learning Cycle-5E) dan kelas baseline (pembelajaran dengan menggunakan model Learning Cycle-5E tanpa disertai Lembar Kegiatan Siswa (LKS) berbasis Learning Cycle-5E), sedangkan pada aspek sikap dan keterampilan tidak terdapat perbedaan.

Hasil-hasil penelitian tentang implementasi Learning Cycle-5E pada pembelajaran sains menunjukkan keberhasilan model ini dalam meningkatkan 
hasil belajar dan kemampuan berpikir siswa. Fajaroh dan Dasna (2007) mengemukakan kekurangan penerapan model learning cycle yang harus selalu diantisipasi adalah sebagai berikut: 1) menuntut kesungguhan dan kreativitas guru dalam merancang dan melaksanakan proses pembelajaran, 2) memerlukan pengelolaan kelas yang lebih terencana dan terorganisasi, 3) memerlukan waktu dan tenaga yang lebih banyak dalam menyusun rencana dan melaksanakan pembelajaran.

\section{Lembar Kegiatan Siswa (LKS)}

Sumber belajar adalah segala sesuatu yang dapat dimanfaatkan oleh siswa untuk mempelajari bahan dan pengalaman belajar sesuai dengan tujuan yang hendak dicapai. Salah satu sumber belajar yang dapat dimanfaatkan oleh siswa adalah Lembar Kegiatan Siswa (LKS). Lembar kegiatan siswa adalah lembaranlembaran yang berisi tugas yang biasanya berupa petunjuk atau langkah untuk menyelesaikan tugas yang harus dikerjakan siswa dan merupakan salah satu sarana yang digunakan guru untuk meningkatkan keterlibatan siswa atau aktivitas dalam proses belajar mengajar (Depdiknas, $2005: 4$ ).

Menurut Prastowo (2011) seperti yang dikutip oleh Diana Deri (2015) mengatakan setidaknya ada empat poin tujuan penyusunan LKS, antara lain (1) menyajikan salah satu bahan ajar yang memudahkan siswa untuk berinteraksi dengan materi yang diberikan, (2) menyajikan tugas-tugas yang meningkatkan penguasaan siswa terhadap materi yang diberikan, (3) melatih kemandirian belajar siswa, (4) memudahkan guru dalam memberikan tugas kepada peserta didik.

\section{Penerapan Learning Cycle 5E Dalam Pembelajaran Tata Nama Senyawa Anorganik}

Alternatif pemecahan untuk mengatasi berbagai permasalahan dalam pembelajaran kimia khususnya materi tata nama senyawa anorganik salah satunya dengan menerapkan metode pembelajaran yang sesuai. Upaya dalam meningkatkan minat, perstasi belajar dan rasa ingin tahu siswa dapat ditempuh dengan metode pembelajaran konstruktivisme melalui penggunaan LKS berbasis Learning Cycle-5E.

Pada pembelajaran digunakan Lembar Kegiatan Siswa (LKS) sebagai media dalam memuat tugas-tugas siswa yang dapat dikerjakan siswa secara kolaboratif di dalam kelompok. LKS yang digunakan dibuat sendiri oleh guru yang disesuaikan dengan kondisi kegiatan pembelajaran di kelas.

Dalam kurikulum 2013, materi tata nama senyawa anorganik merupakan sub materi pokok dari KD 3.9 Mengidentifikasi reaksi reduksi dan oksidasi menggunakan konsep bilangan oksidasi unsur dan KD 4.9 Menganalisis beberapa reaksi berdasarkan perubahan bilangan oksidasi yang diperoleh dari data hasil percobaan dan/ atau melalui percobaan. Dalam memahami konsep tata nama senyawa kimia, siswa sebelumnya harus mengetahui tentang nama unsur, lambang unsur, muatan, bilangan oksidasi, dan aturan penamaan senyawa serta penulisan rumus kimianya. Prasyarat tersebut perlu diketahui dan dipahami agar siswa tidak mengalami kesulitan dalam memahami konsep tata nama senyawa kimia. Tata nama senyawa anorganik terbagi menjadi beberapa sub bagian, yaitu: (1) tata nama senyawa anorganik biner logam dan nonlogam; (2) tata nama senyawa anorganik biner nonlogam dan nonlogam; (3) tata nama senyawa 
anorganik yang mengandung ion poliatom;

(4) tata nama senyawa asam anorganik; dan (5) tata nama senyawa basa anorganik.

Materi pembelajaran tata nama senyawa kimia anorganik yaitu:

- Fakta : Nama beberapa senyawa yang digunakan dalam kehidupan sehari-hari

- Konsep : Bilangan oksidasi dalam suatu senyawa

- Prinsip : Aturan IUPAC untuk penamaan senyawa anorganik

- Prosedur : Tahapan pemberian nama senyawa anorganik

Setelah proses pembelajaran selesai, diharapkan siswa dapat:

1. Memberikan nama senyawa anorganik menurut IUPAC.

2. Menentukan rumus kimia dari suatu senyawa anorganik.

3. Menghubungkan konsep biloks dalam menentukan nama senyawa.

Berikut aktivitas belajar yang diharapkan terjadi dengan penggunaan LKS berbasis Learning Cycle-5E pada pembelajaran tata nama senyawa anorganik.

Tabel 2. Aktivitas Guru dan Siswa pada pembelajaran Tata Nama Senyawa Anorganik

\begin{tabular}{|c|c|c|c|c|}
\hline $\begin{array}{c}\text { No } \\
\text {. }\end{array}$ & $\begin{array}{l}\text { Sintak } \\
\text { Learning } \\
\text { Cycle 5E }\end{array}$ & $\begin{array}{l}\text { Aktivitas } \\
\text { Belajar }\end{array}$ & Aktivitas Guru & Aktivitas Siswa \\
\hline 1. & $\begin{array}{l}\text { Engagemen } \\
\mathrm{t}\end{array}$ & $\begin{array}{l}\text { - } \text { Membangkitka } \\
\text { n minat/rasa } \\
\text { ingin tahu }\end{array}$ & $\begin{array}{ll}\text { - } & \text { Guru } \\
\text { membimbing } \\
\text { siswa untuk } \\
\text { menggunakan } \\
\text { LKS } \\
\text { - Guru } \\
\text { mengajukan } \\
\text { pertanyaan } \\
\text { tentang proses } \\
\text { perkenalan } \\
\text { dikaitkan } \\
\text { dengan materi } \\
\text { tata nama } \\
\text { senyawa. } \\
\text { Guru } \\
\text { menjelaskan } \\
\text { konsep biloks } \\
\text { yang menjadi } \\
\text { prasyarat } \\
\text { pengetahuan. }\end{array}$ & 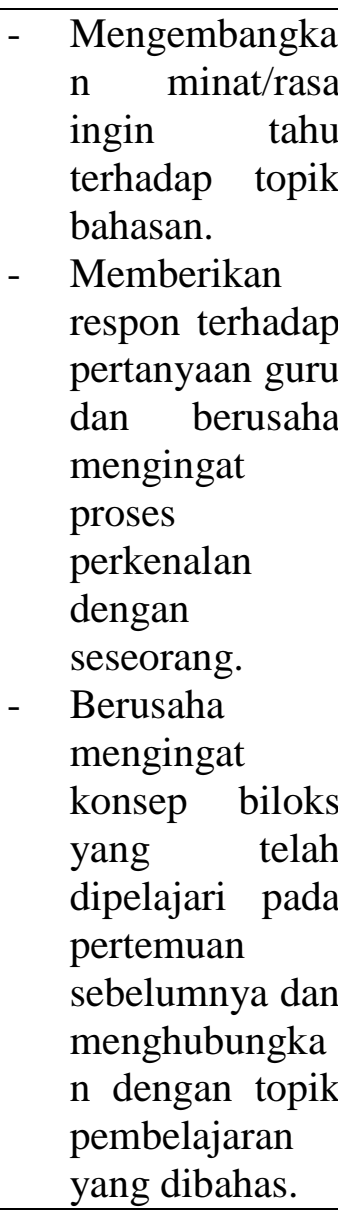 \\
\hline 2. & Eksplorasi & - $\quad$ Diskusi & - $\quad$ Membentuk & - $\quad$ Membentuk \\
\hline
\end{tabular}




\begin{tabular}{|c|c|c|c|c|}
\hline No & $\begin{array}{c}\text { Sintak } \\
\text { Learning } \\
\text { Cycle 5E }\end{array}$ & $\begin{array}{c}\text { Aktivitas } \\
\text { Belajar }\end{array}$ & Aktivitas Guru & Aktivitas Siswa \\
\hline & & Kelompok & $\begin{array}{l}\text { kelompok, } \\
\text { memberi } \\
\text { kesempatan } \\
\text { untuk bekerja } \\
\text { sama dalam } \\
\text { kelompok kecil } \\
\text { secara mandiri. } \\
\text { - Guru berperan } \\
\text { sebagai } \\
\text { fasilitator. } \\
\text { Mendorong } \\
\text { peserta didik } \\
\text { untuk } \\
\text { menjelaskan } \\
\text { tentang } \\
\text { penulisan } \\
\text { rumus kimia } \\
\text { yang telah } \\
\text { diketahui } \\
\text { beserta nama } \\
\text { senyawa dan } \\
\text { cara memberi } \\
\text { nama senyawa- } \\
\text { senyawa kimia } \\
\text { tersebut dengan } \\
\text { kalimat mereka } \\
\text { sendiri. } \\
\text { Meminta bukti } \\
\text { dan klarifikasi } \\
\text { penjelasan } \\
\text { peserta didik, } \\
\text { mendengar } \\
\text { secara kritis } \\
\text { penjelasan antar } \\
\text { peserta didik. } \\
\text { Memberi } \\
\text { penjelasan } \\
\text { dengan } \\
\text { memakai } \\
\text { penjelasan } \\
\text { peserta didik } \\
\text { terdahulu } \\
\text { sebagai dasar } \\
\text { diskusi. }\end{array}$ & $\begin{array}{l}\text { kelompok dan } \\
\text { berusaha } \\
\text { bekerja dalam } \\
\text { kelompok. } \\
\text { - } \\
\text { prembuat } \\
\text { tentang baru } \\
\text { penulisan } \\
\text { rumus kimia } \\
\text { yang telah } \\
\text { diketahui } \\
\text { beserta nama } \\
\text { senyawa dan } \\
\text { cara memberi } \\
\text { nama senyawa- } \\
\text { senyawa kimia } \\
\text { tersebut dengan } \\
\text { kalimat sendiri. } \\
\text { Mencoba } \\
\text { alternatif } \\
\text { pemecahan } \\
\text { dengan teman } \\
\text { sekelompok, } \\
\text { mencatat hasil } \\
\text { diskusi, serta } \\
\text { mengembangka } \\
\text { n ide baru. } \\
\text { Menunjukkan } \\
\text { bukti dan } \\
\text { memberi } \\
\text { klarifikasi } \\
\text { terhadap ide-ide } \\
\text { baru melalui } \\
\text { tabel hasil } \\
\text { diskusi. } \\
\text { Mencermati } \\
\text { dan berusaha } \\
\text { memahami } \\
\text { penjelasan guru }\end{array}$ \\
\hline 3. & Eksplanasi & - $\quad$ Presentasi & Mendorong & Mencoba \\
\hline
\end{tabular}




\begin{tabular}{|c|c|c|c|c|}
\hline $\begin{array}{c}\text { No } \\
\text { • }\end{array}$ & $\begin{array}{c}\text { Sintak } \\
\text { Learning } \\
\text { Cycle 5E }\end{array}$ & $\begin{array}{l}\text { Aktivitas } \\
\text { Belajar }\end{array}$ & Aktivitas Guru & Aktivitas Siswa \\
\hline & & $\begin{array}{ll}\text { Kelas } \\
-\quad \text { Studi } \\
\text { Literatur }\end{array}$ & $\begin{array}{l}\text { peserta didik } \\
\text { menjelaskan } \\
\text { hasil diskusi } \\
\text { kelompok } \\
\text { dengan kalimat } \\
\text { mereka sendiri } \\
\text { di depan kelas. } \\
\text { - Memandu } \\
\text { diskusi. }\end{array}$ & $\begin{array}{l}\text { memberi } \\
\text { penjelasan } \\
\text { tentang cara } \\
\text { memberikan } \\
\text { nama senyawa } \\
\text { anorganik } \\
\text { menurut } \\
\text { IUPAC serta } \\
\text { hubungan } \\
\text { konsep biloks } \\
\text { dalam } \\
\text { menentukan } \\
\text { nama senyawa. } \\
\text { Menggunakan } \\
\text { tabel hasil } \\
\text { diskusi dan } \\
\text { catatan dalam } \\
\text { memberi } \\
\text { penjelasan. } \\
\text { Melakukan } \\
\text { pembuktian } \\
\text { terhadap } \\
\text { konsep yang } \\
\text { diajukan dan } \\
\text { melakukan } \\
\text { studi literatur } \\
\text { untuk ide- } \\
\text { menyelidiki } \\
\text { sebagai penjelasan } \\
\text { ide } \\
\text { ditemukan. }\end{array}$ \\
\hline 4. & Elaborasi & $\begin{array}{ll}- & \text { Diskusi } \\
& \text { Kelompok }\end{array}$ & 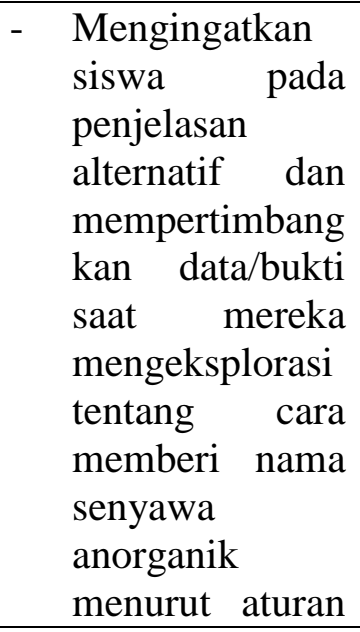 & 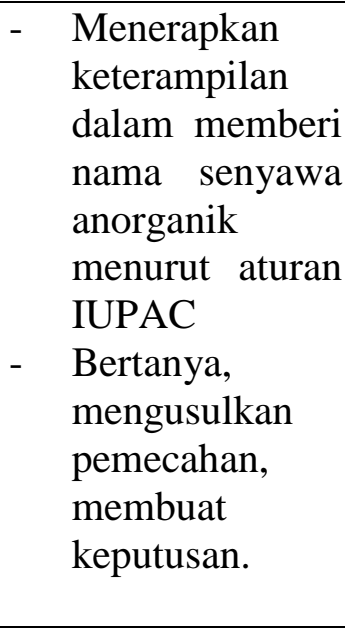 \\
\hline
\end{tabular}




\begin{tabular}{|c|c|c|c|c|}
\hline No & $\begin{array}{c}\text { Sintak } \\
\text { Learning } \\
\text { Cycle 5E }\end{array}$ & $\begin{array}{l}\text { Aktivitas } \\
\text { Belajar }\end{array}$ & Aktivitas Guru & Aktivitas Siswa \\
\hline & & & $\begin{array}{l}\text { IUPAC. } \\
\text { Mendorong dan } \\
\text { memfasilitasi } \\
\text { peserta didik } \\
\text { mengaplikasi } \\
\text { konsep/keteram } \\
\text { pilan dalam } \\
\text { memberi nama } \\
\text { senyawa } \\
\text { anorganik } \\
\text { menurut aturan } \\
\text { IUPAC. }\end{array}$ & \\
\hline 5. & Evaluasi & $\begin{array}{ll}- & \text { Tes } \\
& \text { Pemahaman } \\
& \text { Konsep }\end{array}$ & 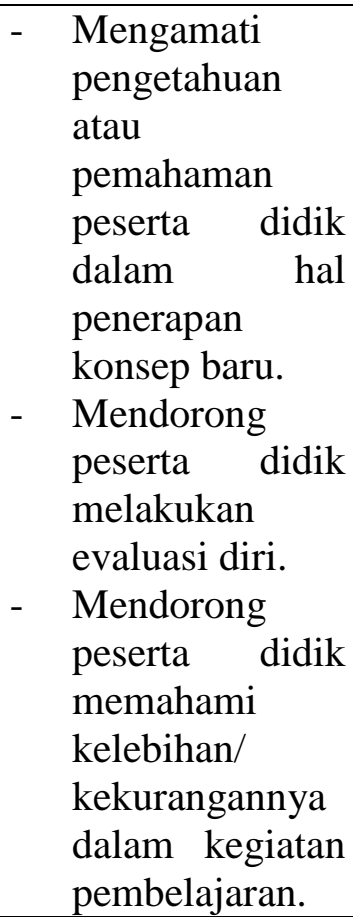 & 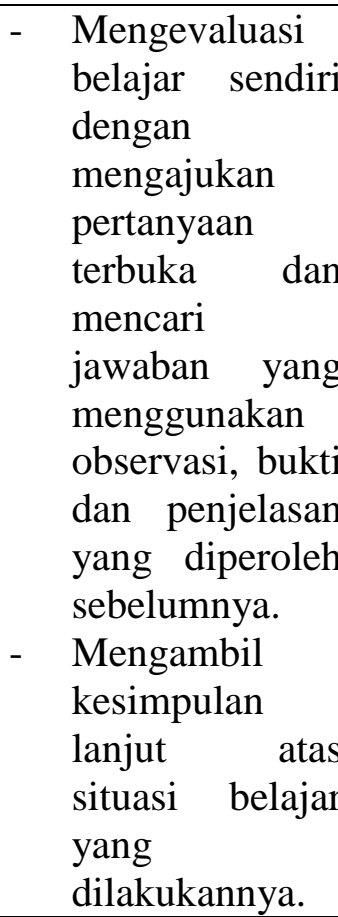 \\
\hline
\end{tabular}

Pada Lembar Kegiatan Siswa sintak pendahuluan atau engagement terdiri atas uraian materi mengenai tata nama senyawa anorganik disertai gambar penunjang untuk membangkitkan minat dan rasa ingin tahu siswa. Pada sintak eksplorasi berisi permasalahan yang disajikan dalam bentuk tabel diskusi. Selanjutnya pada sintak eksplanasi terdapat petunjuk kepada siswa untuk mempresentasikan hasil diskusi di depan kelas serta sintak elaborasi berisi pertanyaan, penugasan, pengayaan atau materi tambahan. Kemudian bagian terakhir adalah sintak evaluasi berisi soal-soal.

Implementasi Learning Cycle dalam pembelajaran sesuai dengan pandangan konstruktivisme yaitu :

1. Siswa belajar secara aktif, siswa mempelajari materi secara bermakna dengan bekerja dan berfikir, pengetahuan dikonstruksikan dari pengalaman siswa. 
2. Informasi baru dikaitkan dengan skema yang telah dimiliki siswa, informasi baru yang dimiliki siswa berasal dari interpretasi individu.

3. Orientasi pembelajaran adalah investigasi dan penemuan yang merupakan pemecahan masalah.

Untuk mengefektifkan penerapan Learning Cycle, maka lingkungan belajar yang perlu diupayakan adalah :

1. Tersedianya pengalaman belajar yang berkaitan dengan pengetahuan yang telah dimiliki siswa

2. Tersedianya berbagai alternatif pengalaman belajar jika memungkinkan

3. Terjadinya transmisi sosial, yakni interaksi dan kerja sama individu dengan lingkungannya

4. Tersedianya media pembelajaran yang memadai

5. Kaitkan konsep yang dipelajari dengan fenomena sedemikian rupa hingga siswa terlibat secara emosional dan sosial yang menjadikan pembelajaran berlangsung menarik dan menyenangkan.

\section{SIMPULAN}

Berdasarkan kajian yang telah dilakukan dapat disimpulkan bahwa penggunaan LKS berbasis Learning Cycle-5E dapat diterapkan dalam pembelajaran tata nama senyawa anorganik yang memerlukan suatu pemahaman konsep untuk meningkatkan hasil belajar dan kemampuan berpikir siswa. Karena proses pembelajaran bukan lagi sekedar transfer pengetahuan dari guru ke siswa, tetapi merupakan proses pemerolehan konsep yang berorientasi pada keterlibatan siswa secara aktif dan langsung melalui kegiatan Engagement, Eksplorasi, Eksplanasi, Elaborasi, dan Evaluasi.

\section{DAFTAR PUSTAKA}

Adam, Budiasih, dan Sukarianingsih. 2013. Perbedaan Hasil Belajar Materi Hidrokarbon Pada Penerapan Model Pembelajaran Learning Cycle $5 E$ Fase danLearning Cycle 5 Fase-Reciprocal Teaching Bagi Siswa Kelas X MAN Malang 1. Universitas Negeri Malang. http://jurnalonline.um.ac.id/data/artikel/artikelA14583542D7A10E0F51D50E6FD2564 9B.pdf (Online) diakses tanggal 2 November 2017.

Dahar, R.W. 2006. Teori-Teori Belajar dan Pembelajaran. Jakarta: Penerbit Erlangga.

Fajaroh, Fauziatul dan Dasna, I Wayan.2007. Pembelajaran Dengan Model Siklus Belajar (Learning Cycle). Jurusan Kimia FMIPA UM. http://lubisgrafura.wordpress.com/2007/09/20/pembelajaran-dengan-model siklus-belajar-learning-cycle/ (Online) di akses 2 November 2017.

Hapsari, Masykuri dan Yamtimah. 2015. Pengembangan Lembar Kegiatan Siswa (LKS) Kimia SMA/MA Berbasis Learning Cycle 5E Pada Materi Laju Reaksi. (http://jurnal.fkip.uns.ac.id/index.php/sains). Jurnal Inkuiri, Vol. 4. diakses tanggal 8 April 2017.

Lailly, dan Wisudawati. 2015. Analisis Soal Tipe Higher Order Thinking Skill (HOTS) Dalam soal UN Kimia SMA Rayon B Tahun 2012/2013. Jurnal Kaunia Vol XI (Online). Diakses tanggal 23 April 2017.

Nugroho, Dasna dan Rahayu. 2016. Pengaruh Learning Cycle 5E-Problem Posing terhadap Hasil Belajar dan Kemampuan Berfikir Tingkat Tinggi 
Siswa dengan Kemampuan awal Berbeda pada Materi Kelarutan dan Hasil Kali Kelarutan. Prosiding Seminar Pendidikan IPA Pascasarja UM, Vol 1 (Online). Diakses tanggal 23 April 2017.

Oktariana, Winda. 2015. Pemahaman Siswa Kelas X SMA Negeri 2 Kahayan Tengah Pada Konsep Tata Nama Senyawa Anorganik sederhana Menggunakan LKS-Induktif Tipe Analogi Tahun Ajaran 2014/2015 (Proposal Tesis). Tidak diterbitkan: Universitas Palangkaraya.

Pipil,F., Lukum dan Ailo. 2013. Penerapan Model Learning Cycle dengan Menggunakan Peta Konsep dapat Meningkatkan Hasil Belajar Siswa pada Materi Tata Nama Senyawa dan Persamaan Reaksi di Kelas X-5 SMA Negeri 1 Tapa. Universitas Negeri Gorontalo. http://docplayer.info/46107006-Kata-kunci-hasil-belajar-siswa-tata-namasenyawa-dan-persamaan-reaksi-siklus-belajar-peta-konsep.html diakses tanggal 3 November 2017.

Sulistyowati, Suyatno dan Poedjiastoeti.2014. Pembelajaran Kimia Dengan Model Learning Cycle 5E Untuk Meningkatkan Penguasaan Konsep dan Keterampilan Berpikir Kritis Siswa SMK Pada Pokok Bahasan Termokimia. Prosiding Seminar Nasional Kimia, ISBN: 978-602-0951-00-3 (Online). Diakses tanggal 12 Mei 2017.

Suyono dan Hariyanto. 2011. Belajar dan Pembelajaran. Bandung: PT Remaja Rosdakarya Offset. 